\title{
UNILATERAL REFUSALS TO SUPPLY AND THE ESSENTIAL FACILITIES DOCTRINE UNDER NEW ZEALAND'S COMPETITION LAW
}

\author{
Paul G Scott*
}

Refusals to supply are one of the types of behaviour that may constitute an illegal act of monopolisation under competition law. As part of United States refusal to supply law the courts developed the essential facilities doctrine. This requires the owner of a facility which is essential to rivals to provide access to that facility. Courts, in particular the United States Supreme Court, have cast doubt on the doctrine and cut back on liability for unilateral refusals to supply. Conversely New Zealand (and Australian) courts have increased liability for refusals to supply. One case, Commerce Commission v Bay of Plenty Electricity Ltd suggested New Zealand has its own essential facilities doctrine. This article discusses and analyses refusals to supply both legally and economically. It compares United States and Australasian law and shows how New Zealand law is tougher on refusals to supply. It argues that New Zealand has its own version of the essential facilities doctrine - albeit for different reasons than the Bay of Plenty Electricity Court suggested. It shows that sound reasons justify this stance.

\section{INTRODUCTION}

Section 36 is the Commerce Act 1986's monopolisation provision that aims to prohibit firms with market power from using that power to eliminate rivals or to protect themselves from competition. ${ }^{1}$

* Senior Lecturer, Faculty of Law, Victoria University of Wellington. I thank Professor Harry First of New York University School of Law for comments on previous drafts of this article.

1 Section 36(2) provides:

A person that has a substantial degree of power in a market must not take advantage of that power for the purpose of-

(a) restricting the entry of a person into that or any other market; or

(b) preventing or deterring a person from engaging in competitive conduct in that or any other market; or 
It seems to have become the Act's forgotten section as litigants no longer allege breaches of it and the Commerce Commission has advocated amending it. ${ }^{2}$ The reason supposedly is that it is too friendly to defendants and cases are too difficult to win. ${ }^{3}$ This is ironical as when it comes to refusals to supply as an act of monopolisation New Zealand's law is plaintiff friendly. Furthermore the Commerce Commission won its last case. ${ }^{4}$ This case concerned a "price squeeze", which involves a vertically integrated monopoly supplier setting prices in a market for an essential input so high that it prevents rivals using that input to compete in an output market. ${ }^{5}$

In determining whether the defendant had engaged in a price squeeze the courts had to decide whether the defendant had a duty to supply. ${ }^{6}$ The reason was that if the defendant was free to refuse to supply then it could not be liable for supplying at a high price. The High Court asserted, following Queensland Wire Industries Pty Ltd v Broken Hill Pty Co Ltd, ${ }^{7}$ that the defendant was obliged to supply. In deciding this it held that the United States "essential facilities doctrine" did not apply in New Zealand. ${ }^{8}$ The Court of Appeal agreed the defendant had a duty to supply and also eschewed relying on the essential facilities doctrine. ${ }^{9}$ It mentioned an earlier case, Commerce Commission v Bay of Plenty Electricity Ltd (BOPE) ${ }^{10}$ which suggested New Zealand had a nascent essential facilities doctrine but said it did not need to comment on it. ${ }^{11}$

Under the United States essential facilities doctrine, the owner of a facility essential to competitors must provide access to that facility. ${ }^{12}$ The doctrine is part of the general law of refusals to supply. In the United States courts have been cutting back on liability for such refusals and casting doubt on the

(c) eliminating a person from that or any other market.

2 Commerce Commission Submission to Targeted Commerce Act Review Issues Paper (10 February 2016).

3 Rex Ahdar "Escaping New Zealand's Monopolisation Quagmire" (2006) 34 ABLR 260; and Rex Ahdar "The Unfulfilled Promise of New Zealand's Monopolisation Law: Sources, Symptoms and Solutions" (2009) 16 CCLJ 291.

4 Telecom Corporation of New Zealand Ltd v Commerce Commission [2012] NZCA 278 [Data Tails].

5 At [2].

6 Commerce Commission v Telecom Corporation of New Zealand Ltd HC Auckland CIV-2004-404-001333, 9 October 2009 [Data Tails] at [126]-[127].

$7 \quad$ Queensland Wire Industries Pty Ltd v Broken Hill Pty Co Ltd (1989) 167 CLR 177.

8 Data Tails, above n 6, at [129].

9 Data Tails, above n 4, at [132].

10 Commerce Commission v Bay of Plenty Electricity Ltd HC Wellington CIV-2001-485-000917, 13 December 2007 [BOPE].

11 Data Tails, above n 4, at [132], n 153.

12 MCI Communications Corp v AT\&T Co 708 F 2d 1081 (7th Cir 1983). 
essential facilities doctrine. ${ }^{13}$ This article demonstrates how New Zealand law has taken a different path with increased liability for defendants refusing to supply. It also argues that New Zealand has its own essential facilities doctrine. To that end Part II of this article outlines the United States law on refusals to supply and essential facilities. The doctrine has been controversial so Part II discusses those criticisms. A feature of Australasian law on refusals to supply is that it is legalistic, relying on cases and statutes rather than economic analysis. Part III discusses the economics of refusals to supply and how they can be anticompetitive. Part IV examines the leading Australasian cases on refusals to supply and how courts have treated the essential facilities doctrine. Part V analyses how and why New Zealand law is tougher on unilateral refusals to supply than United States law. Part VI argues $B O P E$ was correct in suggesting New Zealand has an essential facilities doctrine, albeit for different reasons. Part VII offers some conclusions - in particular that the small size of New Zealand's economy means that often consumers only have one supplier. This means the effects of a refusal to supply are more harmful. Whatever the criticism of the doctrine in the United States, New Zealand is correct to take its own approach.

\section{UNITED STATES LAW}

Section 2 of the Sherman Act governs anticompetitive unilateral behaviour including refusals to deal and provides: ${ }^{14}$

Every person who shall monopolize, or attempt to monopolize, or combine or conspire with any other person or persons, to monopolize any part of the trade or commerce among the several States, or with foreign nations, shall be deemed guilty of a felony ...

A breach of $s 2$ requires: ${ }^{15}$

(1) the possession of monopoly power in the relevant market; and

(2) the wilful acquisition or maintenance of that power as distinguished from growth or development as a consequence of a superior product, business acumen or historic acquisition.

Courts have analysed monopolists' refusals to deal to distinguish between proper and improper refusals under two interrelated approaches: ${ }^{16}$

(1) the intent test; and

(2) the essential facilities doctrine.

13 Verizon Communications Inc v Law Offices of Curtis V Trinko LLP 540 US 398 (2004).

14 Sherman Act 15 USC $\S 2$.

15 United States v Grinnell Corp 384 US 563 (1966) at 570-571.

16 Byars v Bluff City News Co 609 F 2d 843 (6th Cir 1980). 
They have observed the two lines of cases are "conceptually similar"17 and "no bright line can be drawn between them". ${ }^{18}$ Some courts use both.

\section{A Intent Test}

United States $v$ Colgate established the right for a firm to refuse to supply. ${ }^{19}$ The right is qualified as a monopolist cannot refuse to supply if it has the purpose of creating or maintaining a monopoly. The Supreme Court observed: ${ }^{20}$

In the absence of any purpose to create or maintain a monopoly, the [Sherman Act] does not restrict the long recognized right of trader or manufacturer engaged in an entirely private business freely to exercise his own independent discretion as to parties with whom he will deal ...

This was obiter as the case was not under s 2 but rather involved resale price maintenance under s 1 . Subsequent courts used the comments regarding refusal to supply with a purpose to create or maintain a monopoly as the s 2 test and those comments led to the intent test.

The Supreme Court first applied the intent test in Eastman Kodak Co v Southern Photo Materials Co. ${ }^{21}$ Kodak was a monopoly manufacturer of photographic supplies. It not only supplied retail distributors at wholesale but also sold at retail. It decided to integrate vertically to control retail distribution and started buying out its retail rivals. Southern was one such rival and declined to sell. Kodak then refused to sell supplies to Southern at the normal wholesale rate and so Southern alleged Kodak breached s 2. Following Colgate the Court inferred that Kodak's refusal had a purpose to monopolise.

Next was Otter Tail Power Co v United States. ${ }^{22}$ Otter Tail was a vertically integrated power company that produced electricity, transmitted it over its own lines and also sold at retail. It also had a regulated monopoly for transmission services. Three towns decided to establish their own utilities to distribute electricity at retail. They also wanted to buy cheap electricity from Otter Tail's power generating rivals and so asked Otter Tail to sell them electricity at wholesale or to transmit electricity they had bought from generators over its lines. Otter Tail refused as it wanted to prevent the towns from distributing electricity. The Court held this refusal to supply or transmit breached s 2, saying "refusals to sell at wholesale ... were solely to prevent municipal power systems from eroding its

17 At 855 .

18 At 856 .

19 United States v Colgate \& Co 250 US 300 (1919).

20 At 307.

21 Eastman Kodak Co v Southern Photo Materials Co 273 US 359 (1927).

22 Otter Tail Power Co v United States 410 US 366 (1973). 
monopolistic position."23 It rejected Otter Tail's purported justification that it needed to keep its lines free for its own customers.

Justifications were important in Aspen Skiing Co v Aspen Highlands Skiing Corp. ${ }^{24}$ Aspen Skiing Co (Skiing) operated three of the four ski fields in Aspen. Aspen Highlands (Highlands) operated the fourth. For many years the companies sold a six-day pass for all four fields. The firms divided the proceeds according to the fields' usage. Skiing then discontinued the four-field pass. It offered its own three-field pass and refused to sell Highlands lift tickets, even at retail. It also refused to accept vouchers for its fields that Highlands had issued. Highlands sued under s 2 and won at trial and on appeal. The Supreme Court accepted that "even a firm with monopoly power has no general duty to engage in a joint marketing program with a competitor", 25 and held a refusal to deal may "give rise to liability in certain circumstances". ${ }^{26}$ It noted Skiing had "elected to make an important change in a pattern of distribution that had originated in a competitive market and had persisted for several years", ${ }^{27}$ meaning Skiing had made "an important change in the character of the market". ${ }^{28}$ The Court also noted that Skiing used interchangeable tickets in competitive ski areas, which showed such tickets "satisfy consumer demand in free competitive markets". ${ }^{29}$ The Court held conduct breached s 2 if a firm "has been 'attempting to exclude rivals on some basis other than efficiency"'. ${ }^{30}$ In deciding this a court would consider not only the conduct's effect on its rivals but also "its impact on consumers and whether it had impaired competition in an unnecessarily restrictive way". ${ }^{31}$ The Court pointed out how consumers preferred the four-field pass and how discontinuing it harmed Highlands. It examined whether Skiing had valid business reasons for stopping, observing that Skiing failed "to offer any efficiency justification whatever for its pattern of conduct". ${ }^{32}$ It rejected three purported reasons as pretextual.

23 At 378 .

24 Aspen Skiing Co v Aspen Highlands Skiing Corp 472 US 585 (1985).

25 At 600

26 At 601.

27 At 603 .

28 At 604 .

29 At 603

30 At 605 .

31 At 605 .

32 At 608 
The lack of valid business reasons was key in Eastman Kodak Co v Image Technical Services. ${ }^{33}$ Kodak and independent service operators (ISOs) traditionally serviced Kodak copying equipment. Kodak then limited ISOs' ability to obtain replacement Kodak parts by refusing to supply them. In deciding whether Kodak's conduct might be unlawful the Supreme Court focused on Kodak's business justifications. It noted "as a general matter, a firm can refuse to deal with its competitors". ${ }^{34}$ However, that right "is not absolute; it exists only if there are legitimate competitive reasons for the refusal". ${ }^{35}$ "[L]iability turns ... on whether valid business reasons can explain [the defendant's] actions." 36

Verizon Communications Inc v Law Offices of Curtis V Trinko LLP has cut back on s 2 liability. ${ }^{37}$ Verizon was an incumbent local exchange carrier (ILEC) which owned a local telephone network. The 1996 Telecommunications Act required ILECs to share their networks with firms seeking to compete with them - in this case, with competitive local exchange carriers (CLECs). Verizon had to enter an interconnection agreement for the sharing of its network elements with any CLEC who requested interconnection. The plaintiff was the customer of a CLEC who wanted to interconnect with Verizon. Verizon failed to provide access expeditiously so the plaintiff alleged this failure was part of an anticompetitive scheme to discourage customers from becoming or remaining CLEC customers and breached s 2 .

The majority held this did not state a valid claim. It first held the 1996 Act did not prevent competition law applying. It noted: ${ }^{38}$

The mere possession of monopoly power, and the concomitant charging of monopoly prices, is not only not unlawful; it is an important element of the free-market system. The opportunity to charge monopoly prices - at least for a short period - is what attracts "business acumen" in the first place; it induces risk taking that produces innovation and economic growth.

It believed forced sharing under s 2 could cause harm, noting that developing infrastructure could give firms a competitive advantage. Forcing firms to share that infrastructure could be in tension with competition law's underlying purposes as it may lessen the incentive to develop such infrastructure. ${ }^{39}$ Furthermore, forced sharing would require courts to become central planners setting terms of dealing

33 Eastman Kodak Co v Image Technical Services 504 US 451 (1992).

$34 \quad$ At 483.

35 At 483.

36 At 483, n 32.

37 Verizon, above n 13.

38 At 407.

39 At $407-408$. 
for which they are ill-suited and forced sharing could facilitate collusion, which is antitrust's "supreme evil". ${ }^{40}$

The Court reaffirmed the Colgate position that generally firms are free to decide whom they will deal with but that the right to refuse is qualified, saying it had been cautious in recognising liability for refusals to supply. The plaintiff relied on Aspen, which the Court called "the leading case for s 2 liability" for refusals but said it was "at or near the outer boundary of s 2 liability". ${ }^{41}$ However, the Court distinguished Aspen, as key in that case was the defendant ceasing participation in a cooperative venture, which suggested a willingness to forsake short-term profits to achieve an anticompetitive end. Similarly, refusing to supply at retail price showed an "anticompetitive bent". 42 Also the Verizon defendant had never voluntarily dealt with rivals, and nor without the 1996 Act would it have. There was no prior conduct upon which to analyse Verizon's motivation so the Court could not determine whether Verizon was acting out of "competitive zeal" or "anticompetitive malice". ${ }^{43}$ The Court also noted the difference in pricing. The Aspen defendant refused to supply a rival at its retail price, suggesting that once the rival was gone future retail prices would be higher. In Verizon the Federal Communications Commission would set the access price. Furthermore, it was relevant in Aspen that the defendant refused to supply a product that it sold at retail. Similarly, in Otter Tail the defendant refused to supply services to some customers when it supplied those same services to other customers. In Verizon the defendant had never supplied the relevant services and only the 1996 Act forced Verizon to share. This meant the plaintiff's case was not a recognised claim under the Court's precedents.

Furthermore, the 1996 Act governed access to the network. It gave regulatory supervision to regulators. These bodies had found Verizon had breached the Act and so imposed sanctions. Accordingly the Court did not need to extend its refusal to supply law to cover the case because the Act was working. ${ }^{44}$ The Court did not consider whether Verizon had any legitimate business justification for its refusal. In a subsequent price squeeze case, Pacific Bell Telephone Co v linkLine Communications Inc, the Supreme Court, relying on Verizon, referred to the limited circumstances in which a firm's unilateral refusal to deal with its rivals can give rise to antitrust liability. ${ }^{45}$ However, it neither listed nor explained those circumstances.

\author{
40 At 408 . \\ 41 At $408-409$. \\ 42 At 409 . \\ 43 At 409 . \\ 44 At 411 . \\ 45 Pacific Bell Telephone Co v linkLine Communications Inc 555 US 438 (2009).
}


In Verizon the Court referred to the essential facilities doctrine, noting that lower courts had crafted it and that it had never recognised it. It had "no need either to recognize it or to repudiate it here" as the Act governed access so the doctrine served no purpose. ${ }^{46}$ Despite this reluctance the doctrine is the second way United States courts have analysed refusals to supply.

\section{B Essential Facilities Doctrine}

This doctrine holds s 2 requires a single firm that controls a facility essential to its rivals to provide rivals reasonable access to that facility. The doctrine is not separate from the intent test but rather is a specialised version. It derives from three Supreme Court cases, none of which used the phrase. The first, United States v Terminal Railroad Association, was under s $1 .{ }^{47}$ The defendants jointly operated the railroad bridges across the Mississippi River to St Louis and also controlled other facilities which were essential to cross the river by rail. The defendants could grant access to the bridge. The Court held the defendants breached s 1 by denying their rivals access to the facilities on reasonable terms as access was essential to the rivals' ability to compete.

Associated Press $v$ United States also involved s 1 and was a boycott case. ${ }^{48}$ The Associated Press was a joint venture of competing news organisations. Its bylaws prohibited members selling news to non-member competitors. The Court held this breached s 1. Otter Tail was the third case which commentators claimed established the doctrine and involved s $2 .{ }^{49}$

Neale coined the phrase "essential facilities" and used it to describe and analyse the above cases and lower court cases involving a vertically integrated monopolist refusing to deal with a competitor. ${ }^{50}$ The phrase first appeared in Hecht v Pro-Football Inc ${ }^{51}$ while MCI Communications Corp v AT\&T $C o^{52}$ contains the doctrine's standard formulation. AT\&T was a regulated monopolist that controlled the local telephone networks in most United States markets. It faced competition in the long distance market, including from MCI. To compete in that market MCI needed access to AT\&T's local network in order to complete long distance calls over its microwave network. Legal rules prevented MCI from building its own local network and AT\&T refused to allow MCI to interconnect with its local network, claiming business and technological reasons. The Seventh Circuit held AT\&T had no legitimate reasons for refusing. It held the local networks were essential facilities

46 Verizon, above n 13, at 411.

47 United States v Terminal Railroad Association 224 US 383 (1912).

48 Associated Press v United States 326 US 1 (1945).

49 Otter Tail, above n 22.

50 AD Neale The Antitrust Laws of the United States of America: A Study of Competition Enforcement by the Law (2nd ed, Cambridge University Press, New York, 1970).

51 Hecht v Pro-Football Inc 570 F 2d 982 (DC Cir 1978).

52 MCI, above n 12 
and that AT\&T had a duty to allow access. MCI had proved "that it was technically and economically feasible for AT\&T to have provided the requested interconnections" and that AT\&T's refusal was monopolisation. ${ }^{53}$ It said: ${ }^{54}$

A monopolist's refusal to deal under these circumstances is governed by the so-called essential facilities doctrine. Such a refusal may be unlawful because a monopolist's control of an essential facility (sometimes called a "bottleneck") can extend monopoly power from one stage of production to another, and from one market into another. Thus, the antitrust laws have imposed on firms controlling an essential facility the obligation to make the facility available on non-discriminatory terms.

The Court identified four elements necessary to establish liability under the doctrine: 55

(1) control of the essential facility by a monopolist;

(2) a competitor's inability practically or reasonably to duplicate the essential facility;

(3) the denial of the use of the facility to a competitor; and

(4) the feasibility of providing the facility.

Numerous courts have cited these four elements approvingly. Tye reformulated elements (3) and (4) as follows: 56

3. The denial of the use of the facility or the imposition of restrictive terms ... with the consequence of substantial harm to competition in a relevant market in which the monopolist competes (or would be forced to compete with plaintiff(s) absent the practice). 4. The absence of a "valid business reason."

Several courts have added two conditions, namely a plaintiff must show that: ${ }^{57}$

(5) the defendant uses the facility to control a vertically related market; and

(6) the plaintiff is a competitor in either the upstream or downstream market.

The first element focuses on a monopolist's control of an essential facility. To be essential a facility must be vital for competitive viability. Rivals cannot effectively compete without access so

53 At 1133.

54 At 1132 .

55 At 1132-1133.

56 William Tye "Competitive Access: A Comparative Industry Approach to the Essential Facility Doctrine" (1987) 8 Energy LJ 337 at 346.

57 Alaska Airlines Inc v United Airlines Inc 948 F 2d 536 (9th Cir 1991); Intergraphic Corp v Intel Corp $195 \mathrm{~F}$ 3d 1346 (Fed Cir 1999); and Thomas Cotter "The Essential Facilities Doctrine" in Keith Hylton (ed) Antitrust Law \& Economics (Edward Elgar Publishing, Cheltenham, 2010) 157 at 162. 
denying access will cause the plaintiff a severe, long-lasting competitive handicap. ${ }^{58}$ The second and third elements are usually straightforward. Some courts say that denying access requires proving the defendant rejected fair and reasonable terms. ${ }^{59}$ The fourth element poses issues. Courts consider the monopolist's reasons for refusing to grant access. If they are legitimate courts will not require access. Unlike the legitimate business justification concept in Aspen the cases do not require the reasons to be linked to efficiency. Courts will not require access if it is not "technically and economically feasible" for the defendant to provide access.

\section{Criticism of the Essential Facilities Doctrine}

Scholars have criticised the doctrine. ${ }^{60}$ Areeda and Hovenkamp say "the essential facility doctrine is both harmful and unnecessary and should be abandoned". ${ }^{61}$ Critics claim the doctrine is uncertain as disputes arise over what is a facility, what makes it essential and what is a denial of access. Some courts require a monopolist to offer access on "just and reasonable terms" without defining unreasonable access terms. Another criticism is that requiring courts to determine access price and terms makes them regulators. Courts are not best placed to determine the competitive price. As this price may change courts will have an ongoing supervisory role. ${ }^{62}$ The doctrine may harm investment and innovation incentives. ${ }^{63}$ First, compulsory access may decrease the monopolist's incentive to invest and create the facility. Second, knowing the doctrine grants access may decrease the access seeker's incentive to develop its own facilities. ${ }^{64}$

58 Alaska Airlines, above n 57, at 544; Twin Labs Inc $v$ Weider Health \& Fitness 900 F 2d 566 (2nd Cir 1990) at 570; Cotter, above n 57, at 162; and Marina Lao "Search, Essential Facilities and the Antitrust Duty to Deal" (2013) 11 Nw J Tech \& Intell Prop 275.

59 Covad Communications Co v Bell South Corp 299 F 3d 1272 (11th Cir 2002) at 1286-1287; and Cotter, above $\mathrm{n} 57$, at 162 .

60 Donald Baker "Compulsory Access to Network Joint Ventures Under the Sherman Act: Rules or Roulette" (1993) Utah L Rev 999; Michael Boudin "Antitrust Doctrine and the Sway of Metaphor" (1986) 75 Geo LJ 395; Abbott Lipsky and Gregory Sidak "Essential Facilities" (1999) 51 Stan L Rev 1187; Gregory Werden "The Law and Economics of the Essential Facility Doctrine" (1987) 32 St Louis U LJ 433; and United States Department of Justice Competition and Monopoly: Single Firm Conduct Under Section 2 of the Sherman Act (2008) at 127-129 (withdrawn May 2009).

61 Phillip E Areeda and Herbert Hovenkamp Antitrust Law: An Analysis of Antitrust Principles and their Application (2nd ed, Wolters Kluwer, New York, 2002) vol 3A at [771(c)].

62 Frank Easterbrook "When Is It Worthwhile to Use Courts to Search for Exclusionary Conduct" (2003) Colum Bus L Rev 345 at 352; and Lipsky and Sidak, above n 60, at 1248.

63 Phillip Areeda "Essential Facilities: An Epithet in Need of Limiting Principles" (1989) 58 Antitrust LJ 841 at 851; Paul Marquardt and Mark Leddy "The Essential Facilities Doctrine and Intellectual Property Rights: A Response to Pitofsky, Patterson and Hooks" (2003) 70 Antitrust LJ 847; and Brett Frischman and Spencer Weber Waller "Revitalizing Essential Facilities" (2008) 75 Antitrust LJ 1 at 31.

64 Areeda and Hovenkamp, above n 61, at [771(b)]. 
Verizon noted these criticisms and some scholars have suggested that Verizon ended the doctrine. ${ }^{65}$ It narrowed it by excluding it from industries where a regulator determines access, but it did not extinguish it. Hovenkamp says the Court confined it to where: ${ }^{66}$

(a) the claimed facility is essential in the sense that rivals are unable to supply it for themselves, (b) where the facility being claimed is something that the defendant owns fully developed and is actually selling to others, (c) where the sale to rivals would be "rational" in the sense that it is at least as profitable to the defendant as alternative sales, and (d) where there is no regulatory agency actively supervising a compulsory sharing requirement.

The main criticism is that it imposes liability too easily. Proponents counter that courts apply the doctrine narrowly as a defendant will not breach s 2 if it has a legitimate business reason for refusing. ${ }^{67}$ Furthermore, most plaintiffs lose. In "Essential Facilities: An Epithet in Need of Limiting Principles" Areeda cited six cases which he said showed the doctrine's absurdity. ${ }^{68}$ Yet the defendants won five. In the sixth the plaintiff won on the general law of refusal to deal as the Court did not consider the essential facilities doctrine. ${ }^{69}$ Nevertheless Areeda accepted the doctrine can be a useful analytical tool, saying of $M C I$ : "MCI ... which rests on the essential facilities notion, is probably correct." 70

\section{ECONOMICS OF REFUSALS TO DEAL}

One of Areeda's criticisms was that the cases contained little economic analysis and did not consider the benefits and detriments of imposing liability. He commented: ${ }^{71}$

You will not find any case that provides a consistent rationale for the doctrine or that explores the social costs and benefits or the administrative costs of requiring the creator of an asset to share it with a rival. It

65 See for example Frank Schoen "Exclusionary Conduct After Trinko" (2005) 80 NYU L Rev 1625; and Chris Noonan Competition Law in New Zealand (Thomson Reuters, Wellington, 2017) at 483.

66 Herbert Hovenkamp Federal Antitrust Policy: The Law of Competition and its Practice (4th ed, West Publishing, St Paul, 2011) at 337.

67 Spencer Weber Waller "Areeda, Epithets and Essential Facilities" (2008) Wis L Rev 359; Frischmann and Waller, above n 63; Spencer Weber Waller and William Tasch "Harmonizing Essential Facilities" (2010) 76 Antitrust LJ 741; and Robert Pitofsky, Donna Patterson and Jonathan Hooks "The Essential Facilities Doctrine Under United States Antitrust Law" (2002) 70 Antitrust LJ 443.

68 Areeda, above n 63.

69 The case is Aspen, above $\mathrm{n} 24$.

70 Areeda, above n 63, at 845, n 21. See Andrew Gavil, William Kovacic and Jonathan Baker Antitrust Law in Perspective: Cases, Concepts and Problems in Competition Policy (2nd ed, Thomson, St Paul, 2008) at 715716

71 Areeda, above n 63, at 841 . 
is less a doctrine than an epithet, indicating some exception to the right to keep one's creations to oneself,

but not telling us what those exceptions are.

Economic analysis shows that refusals to supply can be anticompetitive but also that imposing liability too easily can harm consumers.

Refusals to supply can harm competition. This only occurs when the defendant refuses to supply a competitor. Refusing to supply a non-rival generally has no anticompetitive effects. Normally a firm wants to deal with a customer that is prepared to pay. Refusing to supply a non-rival must be for reasons that have nothing to do with harming competition and have no such effect. ${ }^{72}$

Usually an anticompetitive refusal to supply arises where a firm is vertically integrated, meaning when it operates at two levels. It makes an input which it and other firms use to make an output; in this way the defendant operates in both upstream (input) and downstream (output) markets. The defendant refuses to provide a rival with the input thus preventing the rival from competing in the output market. For this to be anticompetitive the defendant must have a monopoly or substantial market power in the input market. ${ }^{73}$ If a non-monopolist refuses to supply a rival, the rival can find another firm to supply it and still compete in the output market.

Consumer harm can arise if a monopolist refuses to supply an input. Rivals will have limited or no ability to secure the input. If they cannot obtain the input or a substitute the relevant output market loses a competitor it could have supported. This competitor could have produced more output leading to lower prices. Further, such a refusal will only harm competition if the defendant also has a monopoly in the output market. If that market is competitive then hindering one firm's ability to compete in it will not harm consumers. ${ }^{74}$

Harm may also arise if an input monopolist decides to move into the output market. ${ }^{75}$ It will now use the input itself and not supply rivals. This will foreclose a share of the market that was previously open to rivals. In extreme cases the input monopolist may be able to extend its monopoly to the output market by refusing to sell the input to output rivals. ${ }^{76}$ Whether this leveraging of monopoly power

72 Areeda and Hovenkamp, above n 61, at [736.2(e)].

73 Cotter, above n 57; Kip Viscusi, Joseph Harrington and John Vernon Economics of Regulation and Antitrust (4th ed, MIT Press, Cambridge (Mass), 2005) at 241-242; and Simon Bishop and Mike Walker The Economics of EC Competition Law: Concepts, Application and Measurement (Sweet \& Maxwell, London, 2002) at 238-245.

74 Viscusi, Harrington and Vernon, above n 73; Bishop and Walker, above n 73; and George Hay and Kathryn McMahon "The 'Duty to Deal' under Section 46: Panacea or Pandora's Box?" (1994) 17 UNSWLJ 54 at 56.

75 Viscusi, Harrington and Vernon, above n 73; and Bishop and Walker, above n 72.

$76 M C I$, above n 12, at 1132; and Viscusi, Harrington and Vernon, above n 73, at 241. 
from one market into another harms consumers is controversial but commentators recognise leveraging. ${ }^{77}$

Such refusals can also be anticompetitive by reducing competition in the output market. The refusal forces rivals to enter both markets simultaneously. This can be expensive and a barrier to entry. It means rivals will not be as effective and enables the defendant to keep its output prices high. ${ }^{78}$

These situations involve the defendant being able to raise rivals' costs. This strategy involves a defendant engaging in conduct that raises competitors' costs with the aim and effect of making competitors increase their prices or decrease their output. ${ }^{79}$ This enables the defendant to keep prices high, which harms consumers. $M C I$ is an example. By refusing MCI access to its local telephone networks AT\&T raised MCI's costs of long distance service. This made MCI less effective and prevented price falling. ${ }^{80}$

The refusal need not prevent rivals from entering the output market to be an effective raising rivals' costs strategy. ${ }^{81}$ The rival may have to substitute to inferior or higher cost inputs, thereby decreasing its effectiveness. Aspen is an example. The multi-mountain pass was an input necessary to attract skiers. By denying the plaintiff access to it, the defendant disadvantaged the plaintiff. The plaintiff's sales decreased and it was unable to achieve an adequate customer base to obtain economies of scale. This refusal would raise the plaintiff's costs and make it less effective. The Court recognised this, saying: ${ }^{82}$

In any business, patterns of distribution develop over time; these may reasonably be thought to be more efficient than alternative patterns of distribution that do not develop. The patterns that do develop and persist we may call the optimal patterns. By disturbing optimal distribution patterns one rival can impose costs upon another, that is, force the other to accept higher costs.

77 Richard Posner "The Chicago School of Antitrust Analysis" (1979) 127 U Pa L Rev 925; Louis Kaplow "Extension of Monopoly Power Through Leverage" (1985) 85 Colum L Rev 515; Robin Cooper Feldman "Defensive Leveraging in Antitrust" (1999) 87 Geo LJ 2079; Thomas Piraino "Identifying Monopolists' Illegal Conduct Under the Sherman Act" (2000) 75 NYU L Rev 809; and Noonan, above n 65, at 523-524.

78 Cotter, above n 57, at 172; and Areeda and Hovenkamp, above n 61, at [771(a)].

79 Thomas Krattenmaker and Steven Salop "Anticompetitive Exclusion: Raising Rivals' Costs to Achieve Power Over Price" (1986) 96 Yale LJ 209.

80 American Bar Association Antitrust Section Monograph 18: Nonprice Predation under Section 2 of the Sherman Act (1991) at 64.

81 At 65-69.

82 Aspen, above n 24, at 604, n 31. 
This discussion has focused on short-term static efficiency concerns from refusals to supply. Refusals may have long-term deleterious effects. ${ }^{83}$ A monopolist may be concerned that in the long-term rivals may wish to enter the input market. Refusing to supply output rivals may prevent this. Eliminating output rivals may also discourage other firms from entering the input market. Output rivals are a source of sales that may encourage other firms to enter the input market. Removing output rivals makes this less likely. Thus, refusals can harm long-term efficiency.

Ironically improving long-term efficiency is why some commentators argue that imposing liability for refusals to supply can be harmful. ${ }^{84}$ They argue that making monopolists liable decreases such firms' incentives to invest and innovate. Firms will not do so if the law forces them to share the benefits of their investment and innovation by granting access. Creating and improving a facility can be risky. A firm must consider that once having innovated a court may order it to share that facility with rivals on terms that a court sets. This may decrease their incentive to create. ${ }^{85}$ While an entrant may decrease prices in the short-term this may be at the expense of long-term dynamic efficiency.

This is a property rights argument that firms need ex ante incentives to invest and create property. Property rights provide this and create a desirable environment for investment and innovation. The environment enables firms to enjoy the benefits of investment and innovations or in other words, their property rights. The ability to exclude rivals is one of the greatest incentives to create and improve property. The right to exclude others is a fundamental right in the bundle of rights that constitutes property. Excluding others incentivises not only the creation of facilities but also the ongoing investment in maintaining and enhancing the value of property. Allowing access decreases these incentives and enables access seekers to free ride on the creator's investments.

To enjoy fully the benefits of innovation and investment firms must be free to charge access seekers what they want for their product or service. ${ }^{86}$ The price they charge must fully compensate them for the use of their assets and for the risk they incurred in initially investing. To avoid free riding some scholars argue that entrants should only get access at a price which is equal to its value in the monopolist's hands: that is, the opportunity cost of the incumbent losing the exclusive use of its

83 Cotter, above n 57, at 172; and Einer Elhauge United States Antitrust Law and Economics (Thomson Reuters, New York, 2008) at 260-261.

84 United States Department of Justice, above n 60, at 123.

85 Gavil, Kovacic and Baker, above n 70, at 715-716; Elhauge, above n 83, at 259; Einer Elhauge "Defining Better Monopolization Standards" (2003) 56 Stan L Rev 253 at 296; Lawrence Sullivan, Warren Grimes and Christopher Sagers The Law of Antitrust: An Integrated Handbook (2nd ed, West Academic Publishing, St Paul, 2000) at 126; Glen O Robinson "On Refusing to Deal with Rivals" (2002) 87 Corn L Rev 1177 at 1190 1192; Lao, above n 58; Noonan, above n 65, at 521; and Cotter, above n 57, at 169.

86 Robinson, above n 85, at 1193-1194; Sullivan, Grimes and Sagers, above n 85; and Daniel Troy "Unclogging the Bottleneck: A New Essential Facility Doctrine" (1983) 83 Colum L Rev at 476-479. 
assets. ${ }^{87}$ Such a price fully compensates the firm for the risk it incurred in making its initial and ongoing investments. This can be a monopoly price representing the capture of monopoly profits but it preserves the firm's incentive to invest.

Another criticism of imposing liability for refusals to supply is that it decreases the access seeker's incentives. ${ }^{88}$ Rather than developing its own assets an entrant may seek access under competition law. This reduces its incentives to create its own assets, instead deciding to use an incumbent's technology.

Allowing access therefore skews investment decisions and means less innovation. Liability for refusals to supply is contrary to the law's normal views that firms should compete with their own assets - not their rival's, and that firms should create their own assets and expertise and undertake their own innovation. Scholars from across the ideological spectrum accept that imposing liability can decrease innovation incentives. ${ }^{89}$ Some argue that the incumbent should be free to set its access price as innovation incentives are at their highest when this occurs. ${ }^{90}$ Verizon agreed, noting that compelling sharing "may lessen the incentive for the monopolist, the rival, or both to invest in those economically beneficial facilities". ${ }^{91}$ It referred to "the uncertain virtue of forced sharing"92 and how "[t]he opportunity to charge monopoly prices ... is what attracts 'business acumen' in the first place; it induces risk taking that produces innovation and economic growth." 93

While this decreasing incentives objection is powerful, it is not universal. It only applies where the monopolist created the asset that gave it market power. ${ }^{94}$ Then it "earned" its advantage. The objection does not apply where the monopolist gained a market power by acquiring an asset. In such a case it has no innovation incentive to protect. In the case of former state-owned assets the state did not create the asset to obtain monopoly profits. Such profits did not incentivise the state creating them.

87 William Baumol and Gregory Sidak "The Pricing of Inputs Sold to Competitors" (1994) 11 Yale J on Reg 171 at 199-201; and Gregory Sidak and Daniel Spulber "The Tragedy of the Telecommons: Government Pricing of Unbundled Network Elements Under the Telecommunications Act of 1996" (1997) 97 Colum L Rev 1081 at $1095-1098$.

88 Elhauge, above n 83, at 259; and Areeda and Hovenkamp, above n 61, at [771(b)].

89 Sullivan, Grimes and Sagers, above n 85; Troy, above n 86; Hovenkamp, above n 66, at 321; Herbert Hovenkamp The Antitrust Enterprise Principle and Execution (Harvard University Press, Cambridge (Mass), 2005); and Richard Posner Antitrust Law (2nd ed, University of Chicago Press, Chicago, 2001) at 242.

90 Robinson, above n 84; Troy, above n 86; and Sullivan, Grimes and Sagers, above n 85.

91 Verizon, above n 13, at 408 .

92 At 408 .

93 At 407

94 Elhauge, above n 83, at 272; Elhauge, above n 85, at 305-308; and Sullivan, Grimes and Sagers, above n 85, at 128 . 
Further, allowing access may enable entrants to last long enough to develop their own competing assets, which increases dynamic efficiency. ${ }^{95}$

Verizon identified a danger of liability for refusals to supply. It said that compelling negotiation, which refusal to deal law requires, can lead to and facilitate collusion. ${ }^{96}$ It also claimed that allowing liability has the undesirable effect of turning courts into regulatory agencies. Verizon observed: ${ }^{97}$

We think that Professor Areeda got it exactly right: 'No court should impose a duty to deal that it cannot explain or adequately and reasonably supervise. The problem should be deemed irremedia[ble] by antitrust law when compulsory access requires the court to assume the day-to-day controls characteristic of a regulatory agency.'

Some scholars argue that allowing refusal to supply liability does not result in lower prices. They argue that an incumbent will charge the entrant a monopoly price. The entrant will pass this on to consumers, resulting in the same price as if the incumbent had supplied the market alone. Granting access therefore does not increase consumer welfare but only increases the number of firms in the market. ${ }^{98}$

As this Part indicates, United States courts and commentators have discussed the economics of refusals to supply. The Australasian courts have not.

\section{AUSTRALASIAN CASES ON REFUSALS TO SUPPLY ${ }^{99}$}

The leading authority is Queensland Wire. ${ }^{100}$ The defendant, BHP, produced 97 per cent of Australia's steel and supplied 85 per cent of Australia's steel and steel products. It was the only Australian manufacturer of Y-Bar, an input in making star picket posts. BHP obtained a patent for star picket posts and had been making them since the 1920s. They were Australia's most popular rural fences. Imports were only one per cent of sales. Y-Bar was the only product BHP manufactured that

95 Areeda and Hovenkamp, above n 61, at [771(a)]; Cotter, above n 57, at 171; and Lao, above n 58.

96 Verizon, above $\mathrm{n} 13$, at 408.

97 At 415 .

98 Frischman and Waller, above $\mathrm{n} 63$, at 29.

99 Hay and McMahon, above n 74; Kathryn McMahon "Refusals to Supply by Corporations with Substantial Market Power" (1994) 22 ABLR 7; Brenda Marshall "Pricing Third Party Access to Essential Infrastructure: Principles and Practice" (2005) 24 ARELJ 172; Brenda Marshall and Rachael Mulheron "Access to Essential Facilities under Section 36 of the Commerce Act 1986: Lessons from Australian Competition Law" (2003) 9 Canta LR 248; Warren Pengilley "Misuse of Market Power in Australia: Are the Tests Now Those of Fairness, Efficiency or Business Justification?" (2001) 8 Canta LR 70; and Warren Pengilley "Misuse of Market Power: Present Difficulties - Future Problems" (1994) 2 TPLJ 27.

100 Queensland Wire, above $\mathrm{n} 7$. 
it did not sell to the public. It only sold it to its wholly owned subsidiary, AWI, which used them to make the fences.

The plaintiff, QWI, sold rural fencing products. It also bought star picket posts from BHP and competed with AWI in Queensland. It had 28 per cent of the rural fencing market while BHP had the rest. QWI wanted to make its own star picket posts so it asked BHP to supply it Y-Bar. BHP refused and then offered to supply at "an uncompetitive price" or "an excessively high price". QWI alleged that BHP had first engaged in an actual refusal to supply and then a constructive one.

BHP prevailed at trial and in the Full Federal Court. The High Court held BHP had breached s 46 of the Trade Practices Act 1974 (Cth). It held s 46's object was to protect the interests of consumers. ${ }^{101}$ The issue was whether BHP had taken advantage of its substantial market power. Four judges held that for conduct to be a taking advantage of substantial market power there had to be a nexus or linkage between substantial market power and the conduct. In other words, a firm would only engage in that conduct by virtue of its substantial market power. This requires considering whether the firm with substantial market power would have acted in the same way in a competitive market. ${ }^{102}$ If a firm acts differently than it would in a competitive market then it has taken advantage of its market power. They held that BHP would have supplied QWI in a competitive market.

The fifth judge, Deane J, used a different test. He inferred a taking advantage from BHP's substantial market power and its anticompetitive purpose. He reasoned BHP's purpose in refusing to supply was to prevent QWI from selling star picket posts. It could only achieve that purpose due to its substantial market power. Therefore by refusing to supply BHP had taken advantage of its market power. ${ }^{103}$

The majority's reasoning became known as the counterfactual test. The Court did not explain what it meant by a competitive market nor did it hear evidence on what BHP would have done in a competitive market. It said BHP would have supplied in a competitive market as Y-Bar was the only product that it did not offer to sell. It had excess capacity in its rolling mills and in a competitive market it would have supplied rather than lose sales. ${ }^{104}$ Also relevant was that BHP did not offer a legitimate reason for refusing to sell. ${ }^{105}$ BHP knew that major distributors insisted on a full range of rural fencing products consisting of posts and wires. By refusing to supply Y-Bar, BHP could keep major distributors to itself.

101 At 191

102 At 192, 202 and 216.

103 At $197-198$.

104 At 185, 193, 197, 202 and 216.

105 At 193 


\section{A Melway}

The next significant s 46 case is Melway Publishing Pty Ltd $v$ Robert Hicks Ltd in the High Court. ${ }^{106}$ Melway had 80-90 per cent of the Melbourne street directory market and had substantial market power in it. Melway had a selective distribution system for its directories. It divided the retail market into segments and appointed exclusive wholesalers to each segment. There was strong retail competition, but in general wholesalers could only sell to their segment. Thus, there was no competition between wholesalers in each segment. Melway believed the system was efficient and maximised sales. It had used this system ever since it began in Melbourne. Melway decided to terminate one of its wholesalers (Robert Hicks) and appoint another in its place. Hicks broke into two companies. Hicks, the previous wholesaler, asked that Melway supply it with 20,000-50,000 directories for sales to its previous segment and new customers. Hicks was going to ignore Melway's segmented distribution system and sell to whom it wanted. Melway refused. Hicks sued.

The majority of the High Court characterised the conduct, not as a refusal to supply, but rather as Melway maintaining its distribution system. ${ }^{107}$ It endorsed the counterfactual test for taking advantage. It explained that the counterfactual did not have to be perfect competition but "only requires a sufficient level of competition to deny a substantial degree of power to any competitor in the market". ${ }^{108}$ It decided Melway had not taken advantage of its market power, as it would have refused to supply Hicks in order to maintain its distribution system even if it had no market power. It noted the pro-competitive effects of such a system and how Melway had used such a system when it lacked market power. ${ }^{109}$

The High Court noted some qualifications to the Queensland Wire counterfactual approach in that asking how a firm would behave if it lacked market power involved economic analysis. ${ }^{110}$ This was only valid if it could be undertaken with sufficient cogency. ${ }^{111}$ As counterfactual analysis may not be cogent in all cases the court recognised other tests, in particular, Deane J's purpose test $\mathrm{t}^{112}$ and the material facilitation test noting that s 46 "would be contravened if the market power which a

106 Melway Publishing Pty Ltd v Robert Hicks Pty Ltd t/as Auto Fashions Australia [2001] HCA 13, (2001) 205 CLR 1.

107 At [61].

108 At [52].

109 At [62].

110 At [52].

111 At [52].

112 At [48]. 
corporation had made it easier for the corporation to act for the proscribed purpose than otherwise would be the case". 113

\section{$B$ NT Power}

Next is NT Power Generation Pty Ltd $v$ Power and Water Authority. ${ }^{114}$ Power and Water Authority (PAWA) was a Northern Territories government-owned business. It was a vertically integrated electricity company which generated electricity and transmitted it along its own power transmission lines. It also owned distribution facilities and retailed electricity. NT Power generated electricity at a power station and wanted to sell this electricity to consumers in competition with PAWA. To do so it needed access to PAWA's transmission and distribution facilities as to build its own was too expensive. PAWA declined access "for no reason of want of capacity or technical difficulty or safety, but simply in order to protect its revenue position in relation to electricity sales". ${ }^{115}$ It claimed it was waiting for an access regime. NT Power sued.

The majority of the High Court held PAWA liable. It adopted Finkelstein J's reasoning in the Full Federal Court where he held PAWA had taken advantage of its substantial market power using the "unexceptional" counterfactual test ${ }^{116}$ and Deane J's purpose approach. ${ }^{117}$ As for counterfactual analysis he considered how a firm would have acted in a competitive market in which he assumed: ${ }^{118}$

(a) PAWA had the capacity to allow third parties to use its infrastructure to supply and distribute electricity in competition with it.

(b) PAWA had at least one competitor with similar infrastructure in the same geographic region that also had the capacity to allow third parties to use its infrastructure.

(c) PAWA and its hypothetical competitor were willing to make their infrastructure available to third parties on reasonable terms and conditions. A reasonable price was one which would give a reasonable return to the infrastructure's owner.

(d) In the downstream electricity supply market PAWA would lose business to an effective competitor.

Finkelstein $\mathbf{J}$ held in such a market PAWA would have provided NT Power with access to its infrastructure as firstly, "[a] profit maximising firm in a competitive market for transmission and

113 At [51].

114 NT Power Generation Pty Ltd v Power and Water Authority [2004] HCA 48, (2004) 219 CLR 90.

115 At [72].

116 NT Power Generation Pty Ltd v Power and Water Authority [2002] FCAFC 302, (2003) ATPR 41-909 at [175].

117 At [180].

118 At [177]-[178]. 
distribution would not stand by and allow a competitor to supply the third party with [its] facilities."119 It would at least bid for the business. ${ }^{120}$ Secondly, even though granting access would allow a third party to compete with PAWA in the downstream electricity supply market, PAWA would not deny supply as it could not prevent such competition. The reason was that a third party could get access to the hypothetical competitor's infrastructure and it would be impossible for PAWA to keep the third party away from its customers. ${ }^{121}$ Therefore, Finkelstein found PAWA had taken advantage as it would not be rational for it to deny access to its infrastructure.

He reached the same result using Deane J's purpose test. He held:122

Just as BHP had the capacity to prevent QWI from becoming a manufacturer of star pickets in Queensland

Wire, so here PAWA had the capacity to keep NT Power out of the electricity supply market. It had that

power because it was the monopolist in the transmission and distribution markets. I regard the conclusion

that PAWA used its market power in those markets to keep NT Power out of the electricity supply market

as self-evident. The implementation of PAWA's purpose of preventing NT Power from becoming a

supplier of electricity ... was to take advantage of its monopoly power.

The High Court majority agreed. As for his counterfactual approach the Court held his hypothetical competitive market was not "beyond the realms of reality". ${ }^{123}$ While a court could make unrealistic assumptions about the hypothetical competitive market its analysis must be cogent on the basis of the assumptions. ${ }^{124}$ The Court held Finkelstein J's approach was sound because if it was not then it would be very difficult ever to show that a firm whose monopoly power depends on infrastructure had taken advantage of a substantial market power. ${ }^{125}$ It also agreed with how Finkelstein J applied Deane J's test, saying that PAWA in denying access to infrastructure had the purpose of excluding NT Power from the market. PAWA could only achieve that purpose because of its substantial market power. ${ }^{126}$

PAWA also argued that it was not taking advantage of substantial market power - rather, it was taking advantage of its property rights. It said s 46 should not interfere with its property rights. The Court rejected this. It said that to suggest a distinction existed between taking advantage of market

119 At [179].

120 At [179].

121 At [179].

122 At [180].

123 NT Power, above n 114, at [143].

124 At [145].

125 At [147].

126 At [150]. 
power and taking advantage of property rights was to suggest a false dichotomy that lacked any basis. ${ }^{127}$ It pointed out how s 46 can apply to intellectual property ${ }^{128}$ and how property rights can be a source of market power. ${ }^{129}$ This suggested s 46 "can apply to the use of market power derived from other property rights not specifically mentioned in the Act". ${ }^{130}$ It said that the "proposition that a property owner who declines to permit competitors to use the property is immune from s $46 \ldots$ is ... intrinsically unsound". ${ }^{131}$

\section{$C$ Telecom v Clear}

Telecom Corporation of New Zealand Ltd v Clear Communications Ltd involved an access dispute. ${ }^{132}$ Until 1987 New Zealand's telecommunications was a government monopoly. The government first corporatised telecommunications with Telecom Corporation of New Zealand acquiring the telecommunications system. After opening the market to competition the government privatised Telecom. Clear was an entrant and wanted to provide a local telephone service in the central business districts of some cities in competition with Telecom. It needed access to Telecom's Public Service Telephone Network (PSTN). Telecom had given undertakings to the government that it would facilitate the emergence of competition by providing interconnection on fair and reasonable terms and conditions. ${ }^{133}$

Thus, there was no dispute about whether Telecom had to grant Clear access. The dispute was over access terms - in particular the price Clear should pay. Telecom eventually offered access on the basis of what the courts called the Baumol-Willig rule, now known as the Efficient Component Pricing Rule (ECPR). This is based on the principle that: ${ }^{134}$

... where a firm supplies components or intermediate goods to another firm, "... and this process entails some sacrifice of profit by the supplier firm (as when it thereby gives up some capacity that it would otherwise have used itself), then the supplier firm must be permitted to price the article in question at a

127 At [125].

128 At [85].

129 At [125].

130 At [85].

131 At [126].

132 Telecom Corporation of New Zealand Ltd v Clear Communications Ltd [1995] 1 NZLR 385 (PC).

133 Letter from Patrick Troughton (Managing Director of Telecom) to the Ministers for State Owned Enterprises and Finance (8 June 1988); Letter from Telecom to Minister of Commerce (6 July 1989); and Ross Patterson "Light-Handed Regulation in New Zealand Ten Years on" (1998) 6 CCLJ 134 at 137-138.

134 Clear Communications Ltd v Telecom Corporation of New Zealand Ltd (1993) TCLR 166 (HC). 
level sufficient to compensate it for the profit it is forced to sacrifice because of its supply to another firm ...

Therefore, Telecom could charge Clear:

(a) Telecom's average incremental cost of supplying the PSTN; and

(b) the revenue Telecom would have received if it had supplied the service to Clear's customers; minus

(c) the cost Telecom saved due to Clear providing calls to and from Clear's customers.

Clear alleged this pricing breached s 36 , claiming the rule "offends common sense; it requires Clear to underwrite Telecom's current profits and level of operating efficiency". ${ }^{135}$ Clear's main objection was that the rule enabled Telecom to recover any monopoly profits that may have existed.

The High Court accepted this. ${ }^{136}$ However, it held that Baumol-Willig pricing did not breach s 36 as Telecom lacked an anticompetitive purpose. ${ }^{137}$ The Court of Appeal reversed this, holding the rule breached s 36. ${ }^{138}$ Gault J said "I cannot accept that the objects of the Commerce Act are served by a method of pricing that secures the profits of a firm in a dominant position." $139 \mathrm{He}$ also rejected the High Court ruling that if the rule improved efficiency then Telecom's conduct did not breach $\mathrm{s}$ $36 .{ }^{140}$

The Privy Council allowed Telecom's appeal, holding Baumol-Willig rule pricing did not breach s 36 and while Telecom had a proscribed purpose it had not used its dominant position. It said: ${ }^{141}$

Both the High Court and the Court of Appeal proceeded on the basis, with which Their Lordships agree, that if the terms Telecom were seeking to extract were no higher than those which a hypothetical firm would seek in a perfectly contestable market, Telecom was not using its dominant position. In order to discover what such hypothetical terms might be it is inevitable that the parties and the court must have recourse to expert economic evidence. The Baumol-Willig Rule is a closely reasoned economic model which seeks to show how the hypothetical firm would conduct itself.

It held the presence of actual or potential monopoly profits was the principal issue and that Clear had not proved that Telecom's charges included monopoly rents. Without such rents charging Baumol-

135 At 207.

136 At 212 .

137 At 217.

138 Clear Communications Ltd v Telecom Corporation of New Zealand Ltd (1993) 5 TCLR 413 (CA).

139 At 436.

140 At 436.

141 Telecom, above n 132, at 403. 
Willig prices would not breach s 36 . The risk of monopoly rents had no bearing on whether the rule prevented competition between Telecom and Clear. It found this as Clear had not established that Telecom charges would be so high that Clear could not compete. ${ }^{142}$ Thus, the rule did not prevent Clear from entering the market.

The Privy Council also noted that pt IV of the Act allowed for price control. If monopoly profits were a concern then the government could institute price control. It would be wrong to interpret s 36 to eliminate monopoly profits when the Act provided a remedy. ${ }^{143}$

\section{Australasian Essential Facilities Cases}

While the Australasian final courts have considered refusals to deal they have not dealt with the essential facilities doctrine. Lower courts have discussed it and mainly rejected it. In Australia, the court to most consider it was the Full Federal Court in Queensland Wire. ${ }^{144}$ In that case the plaintiff relied on United States essential facilities law to argue BHP had to supply Y-Bar. The Court held the doctrine did not apply to s 46 for a number of reasons. First, the doctrine did not easily fit the terms of s 46. Second, the doctrine evolved as a gloss on the Sherman Act. Third, the Court had difficulty in seeing the doctrine's limits in cases not involving a monopoly of electric power, transport or communications. Fourth, even if the doctrine existed, difficulty arose when an applicant asked the court to oblige a respondent to accept the applicant as a customer. Fifth, the doctrine seemed to conflict with holding a respondent not liable if it refused for a legitimate business purpose. Sixth, the doctrine only applied to cases involving discriminatory refusals to deal rather than to a vertically integrated monopolist who refused to supply an intermediate product and was using that product for its own use. ${ }^{145}$ The Court said the United States cases assisted but were not compelling. ${ }^{146}$ On appeal, in regards to the essential facilities doctrine the High Court was silent.

Auckland Regional Authority v Mutual Rental Cars (Auckland Airport) Ltd (ARA) was the first New Zealand case to discuss the doctrine. ${ }^{147}$ Barker J said an essential facility was a "facility which is incapable of duplication ... and to which others must have access if they are to compete in a given market". ${ }^{148} \mathrm{He}$ did not adopt the doctrine entirely but used it in holding Auckland International

142 At 404 and 407

143 At 408 .

144 Queensland Wire Industries Pty Ltd v Broken Hill Pty Co Ltd (1987) 16 FCR 50 (FCAFC).

145 At [38].

146 At [39].

147 Auckland Regional Authority v Mutual Rental Cars (Auckland Airport) Ltd [1987] 2 NZLR 647 (HC).

148 At 679 
Airport was a separate and identifiable geographic market for car hire services. The doctrine also showed how the defendant had an anticompetitive purpose.

Conversely, the High Court in Union Shipping NZ Ltd v Port Nelson Ltd disliked the doctrine. ${ }^{149}$ This case involved access to wharf facilities. The plaintiff argued the facilities were an essential facility. The Court used the MCI Communications requirements and declined to incorporate the doctrine "as is" into New Zealand. It gave five reasons: ${ }^{150}$

(1) The doctrine derives from a distinctively American setting.

(2) The doctrine is based on ss 1-2 of the Sherman Act, which differ from s 36.

(3) It was reluctant to incorporate into New Zealand a controversial doctrine that the United States Supreme Court had not tested, noting "[a] wrong turning ... may prove painfully difficult to correct."

(4) The Full Federal Court had criticised the doctrine in Queensland Wire and the High Court's silence was enigmatic. While the New Zealand High Court did not necessarily share all the Full Federal Court's criticisms, it was wise to await further developments.

(5) The Court had to interpret the Commerce Act. This was not a matter of importing common law doctrine. However, United States law might give valuable insights.

While not adopting the doctrine the Court noted it would have reached the same outcome had it applied it. 151

Gault $\mathrm{J}$ invoked the doctrine in Clear as an evidentiary aid, noting: ${ }^{152}$

In cases involving direct dealings with, or refusals to deal by, a firm alleged to be dominant in a market by the ownership or control of facilities without access to which others cannot enter it may be helpful in determining whether there has been use of the dominant position merely to consider whether the firm has acted reasonably or with justification. Again, this should not be regarded as a substitute for the requirements of the section. What may be perceived in one view to be reasonable or fair may still contravene ... Such an approach ... comes close to the so-called "essential facilities" doctrine which, although invoked well beyond its usefulness in some cases, is not totally discredited ...

He used the doctrine to show use of a dominant position rather than anticompetitive purpose as in ARA. The Privy Council did not mention essential facilities but was unimpressed with the "act[ing] reasonably or with justification" language, saying this would put a monopolist of an essential service

149 Union Shipping New Zealand Ltd v Port Nelson Ltd [1990] 2 NZLR 662 (HC).

150 At $705-706$.

151 At 711 .

152 Clear, above n 138, at 430. 
in an impossible position as it could not know what a court would find to be reasonable or justifiable. $^{153}$

The next case to discuss essential facilities was BOPE. ${ }^{154}$ The defendant acquired the electricity supply business of a local energy company called Bay of Plenty Electricity (BOPE). It bought 20,000 electricity meters located at customers' premises. The relevant legislation encouraged competition among electricity supply companies. ${ }^{155}$ Rivals wanted to compete against BOPE and asked for access to its meters. If rivals took a customer from BOPE they wanted to use BOPE's meters. Most electricity supply incumbents agreed to lease their meters to rivals but BOPE did not. This meant rivals either had to install their own meters or buy them from BOPE.

The Commerce Commission claimed buying meters from BOPE or installing their own was not economically viable as they were no substitutes for leasing. ${ }^{156}$ Thus, refusing to lease meters breached s 36. The Court characterised the Commission's claims in two ways. ${ }^{157}$ First, as an unlawful refusal to supply an essential facility. Secondly, by refusing access to its meters BOPE raised barriers to entry. This raised rivals' costs and was anticompetitive strategic behaviour. ${ }^{158}$

\section{E Essential Facility Case}

Relying on four cases BOPE argued its meters were not an essential facility. ${ }^{159}$ It further argued that if BOPE was liable then the Court must hold that BOPE was legally obliged to supply. This meant the Court would have to determine the price of supply as if it did not have oversight the obligation to supply would be meaningless. ${ }^{160}$ Accordingly the Court would become the regulator of the defendant's conduct. ${ }^{161}$ Relying on Verizon BOPE argued courts are not well placed to regulate prices. ${ }^{162}$ The Court recognised the logic of these submissions. ${ }^{163}$ BOPE also argued it had a

153 Telecom, above n 132, at 403.

154 BOPE, above n 10.

155 Electricity Industry Reform Act 1998; and BOPE, above n 10, at [1].

$156 B O P E$, above n 10, at [14]

157 At [356].

158 At [369].

159 At [373].

160 At [374].

161 At [377].

162 At [379].

163 At [374]. 
legitimate business rationale for not supplying. ${ }^{164}$ The Commission said it only had to establish s 36's elements. It did not have to show that BOPE's actions had harmed competition or created inefficiencies. ${ }^{165}$

The Court said a firm with lawfully acquired monopoly power was not required to assist its competitors, nor hold an umbrella over inefficient competitors. It was entitled to compete. Section 36 neither prevents a lawfully acquired monopoly operating, nor forbids it from collecting monopoly profits. Rather s 36 aims to produce competition. ${ }^{166}$

The Court accepted that the essential facilities doctrine, as contained in the four cases, qualified those propositions. It noted: ${ }^{167}$

From those cases it would appear that where a firm controls an essential facility or an essential input product it may in certain circumstances be required to supply that product, or access to that facility, at a 'competitive' price. The case that best exemplifies that principle ... is Queensland Wire.

The Court said two factors were always present when a court found an obligation to supply: ${ }^{168}$

(1) An essential facility or input must not be "practically duplicable". Close substitutes cannot exist and the facility or input must be necessary for competition to exist.

(2) The defendant must control the facility or input, which cannot be available elsewhere.

The Court held that BOPE's meters were practically duplicable and enjoyed close substitutes. Rivals could, albeit reluctantly, install their own meters. Meters were unlike the PSTN in Telecom. That was an essential facility as it was not practically duplicable and rivals needed access to compete. Meters were also unlike Y-Bar in Queensland Wire as Y-Bar enjoyed no close substitutes. Here rivals could and did obtain substitutes for BOPE's meter leasing services. ${ }^{169}$

The Court held it was not clear that there was any difference in cost between leasing BOPE's meters and purchasing and installing new meters. In any event, rival retailers were installing

164 At [376].

165 At [381].

166 At [385].

167 At [387].

168 At [388].

169 At [390]. 
meters. ${ }^{170}$ Thus, BOPE's meters were not an essential facility and s 36 did not oblige BOPE to supply. ${ }^{171}$

The Court said it was unclear whether a New Zealand court had applied the essential facilities doctrine to a vertically integrated defendant to force it to unbundle a supply chain at a price that would facilitate competitive entry. ${ }^{172}$ While the New Zealand cases did not do that, Queensland Wire did. The Court held: ${ }^{173}$

To the extent, therefore, that the essential facility/refusal to supply doctrine applies in New Zealand, it is the approach adopted in Queensland Wire ... that we think is applicable to the Commerce Act ..., rather than the essential facilities doctrine as it is applied under ... the Sherman Act ...

\section{F Raising Rival's Costs}

The Commission also characterised BOPE's behaviour as a raising rivals' costs strategy alleging that by forcing rivals to buy and install meters BOPE raised rivals' costs. It submitted that acquiring and installing new meters was more expensive than leasing them. These expenses were additional costs that BOPE forced upon rivals. ${ }^{174}$ The Commission's expert disagreed. He saw no distinction for competition purposes in economic terms between a sale or lease of existing installed meters. BOPE offered to sell its existing meters to rivals. Selling installed meters was economically equivalent to leasing them as was buying and installing them. ${ }^{175}$ Thus, economically BOPE's policy of not leasing meters did not raise rivals' costs. ${ }^{176}$ The s 36 case failed.

\section{$G$ Data Tails}

Data Tails involved a price squeeze where the Commission alleged that Telecom overcharged rivals for access to its wholesale network. ${ }^{177}$ Rival telecommunications service providers (TSPs) sought access to Telecom's network to offer a competing high-speed data transmission service. To do this, rival TSPs needed to purchase data tails from Telecom. Data tails are the connections between an end customer's premises and the point where a TSP can take delivery of data signals from Telecom.

\footnotetext{
170 At [393].

171 At [394].

172 At [395].

173 At [397].

174 At [399].

175 At [411].

176 At [439].
}

177 Data Tails, above n 6. 
They are the last mile connections between a customer's premises and a switch where a TSP can take over the transmission and send it along its network to another customer. ${ }^{178}$

The Commission alleged that Telecom's wholesale price to TSPs for access to data tails was so high relative to Telecom's retail prices that it caused a price squeeze. Telecom sold data tails to TSPs at wholesale. It also provided its own high-speed data transmission service at retail in competition with TSPs. Telecom decreased its retail price but did not commensurately decrease its wholesale price for data tails. In some cases, Telecom's wholesale price of data tails exceeded the retail price of its high-speed data transmission service. This was the price squeeze. The Courts said a price squeeze occurs when a dominant vertically integrated supplier sets prices in the upstream wholesale market in a manner that prevents equally or more efficient competitors from profitably operating in a downstream retail market. ${ }^{179}$

The High Court accepted that Telecom had a substantial degree of market power in the relevant markets. ${ }^{180}$ It held rival TSPs needed access to Telecom's data tails to provide data services to retail customers. As for the hypothetical competitive market (the counterfactual) the parties agreed the characteristics were: (a) two vertically integrated firms each with a ubiquitous access network and 50 per cent of the high-speed transmission market; and (b) an entrant with a core network but lacking ubiquitous access and the ability to construct access economically and thus needing to lease data tails. $^{181}$

The Court looked at whether Telecom had taken advantage of its substantial market power in two steps: first, whether Telecom was obliged to supply data tails; and second, whether the prices Telecom charged its competitors were greater than the prices it would have charged in the hypothetical competitive market. ${ }^{182}$

The Court said no statutory duty or essential facilities doctrine required Telecom to supply. ${ }^{183}$ It held from Queensland Wire that a vertically integrated incumbent had a duty to supply an essential wholesale input to a downstream competitor. Such an obligation was apparently assumed to exist in Telecom v Clear. ${ }^{184}$ As for whether Telecom had to supply the Court neither referred to the agreed counterfactual nor analysed why a firm would supply in the counterfactual. Rather it viewed data tails

178 At [21].

179 At [3]; and Data Tails, above n 4, at [2].

180 It also found Telecom had "dominance" as the government had changed s 36's threshold from dominance to substantial market power during Telecom's behaviour.

181 Data Tails, above n 6, at [129]; and Data Tails, above n 4, at [43].

182 Data Tails, above n 6, at [126].

183 At [127]

184 At [127]. 
as an essential input into providing a high-speed transmission service. ${ }^{185}$ It did not define an essential input but presumably this put the case into the Queensland Wire scenario and thus the Court asserted Telecom had a duty to supply.

As for Telecom's prices the Court, applying Telecom $v$ Clear, endorsed the ECPR as the appropriate model to address how to price network access in markets in which a single vertically integrated provider of network infrastructure and services dominated. The case involved two instances of pricing, one that complied with the ECPR and one that did not. Applying counterfactual reasoning the Court was satisfied that in the agreed counterfactual a Telecom without substantial market power would not set prices above ECPR: ${ }^{186}$

As Professor Ordover said, that is so for the simple reason that if it did so the backbone provider would purchase input from another company and Telecom would lose the sale entirely.

The Court found in pricing above ECPR Telecom took advantage of its substantial market power. Conversely, Telecom did not breach when its pricing complied with the ECPR.

Telecom appealed. The Court dismissed the appeal but allowed the Commission's cross-appeal on the ECPR-compliant pricing. ${ }^{187}$ While the Court accepted the pricing was ECPR-compliant, it held that this outcome would not survive in the hypothetical competitive market. ${ }^{188}$ It said that it would be misreading Telecom v Clear to suggest that the Privy Council endorsed using ECPR to arrive at prices that would preclude competition. ${ }^{189}$ The Court viewed their Lordships as implicitly deciding that an incumbent cannot charge a price above which a rival cannot compete.

Telecom argued that the High Court erred in finding it was obliged to supply data tails as it had not applied the counterfactual test. The Court of Appeal said that while the High Court had not expressly referred to it, in context it had used counterfactual analysis. ${ }^{190}$ The High Court was correct in that Telecom was obliged to supply in the sense that in the agreed counterfactual Telecom would not rationally have refused to supply. As the High Court had not relied on essential facilities the Court of Appeal said it did not need to discuss whether any New Zealand essential facilities doctrine exists

185 At [128].

186 At [129].

187 Data Tails, above n 4.

188 At [246].

189 At [235].

190 At [132]. 
following BOPE. ${ }^{191}$ It further said Telecom $v$ Clear ${ }^{192}$ and Queensland Wire ${ }^{193}$ were indistinguishable from the present case. It also relied on NT Power in establishing that counterfactual principles obliged Telecom to supply. ${ }^{194}$

In the cross-appeal the Court held ECPR-compliant pricing meant rivals could not compete as such pricing meant rivals could not cover their fixed or common costs. Accordingly, they would not enter. ${ }^{195}$

This discussion shows that the way New Zealand (and Australian) courts have dealt with refusals to supply differs from United States law.

\section{HOW NEW ZEALAND LAW ON REFUSALS TO SUPPLY IS TOUGH ON DEFENDANTS}

Australasian law imposes liability for unilateral refusals to supply more easily than the United States. Queensland Wire is the prime example. After Verizon, a United States court would not decide Queensland Wire the same way as the High Court of Australia. This is because BHP had never sold Y-Bar [the product] to anyone. Following Verizon courts will only impose liability in rare circumstances like Aspen or Otter Tail. ${ }^{196}$ In Aspen the defendant had stopped participating in a voluntary cooperative venture. It also refused to supply a rival with a product that it already sold at retail. In Otter Tail the defendant already supplied the relevant services to some customers but refused to supply them to the plaintiff. Absent these circumstances, which the Supreme Court said were at or near the outer boundary of liability, United States courts will not find liability for refusing to supply. ${ }^{197}$

Post-Verizon, the Supreme Court would not order a firm to supply services or products that it used for itself and had never supplied to others. Under United States law only a statute can compel a vertically integrated firm to unbundle part of its supply chain and offer an intermediate product or service to rivals when it had used all of the product or service for itself. ${ }^{198}$ Yet that is what happened in Queensland Wire. Indeed, Toohey J said "[t]he claim was in truth one for divestiture." ${ }^{199}$ As

191 At [132], n 153.

192 At [136]-[137].

193 At [141].

194 At [138]-[140].

195 At [234]-[237].

196 Verizon, above n 13, at 409-410.

197 At 409.

198 At 410.

199 Queensland Wire, above n 7, at 208. 
mentioned, BHP had never sold Y-Bar to anyone but consumed it itself. This did not help it - rather, it contributed to the Court finding it liable. That Y-Bar was the only product it did not sell to the public showed it had taken advantage as according to the Court it would supply in a competitive market. ${ }^{200}$ Australasian law thus does not require previous dealing before imposing liability.

Part of the reason the Verizon Supreme Court was reluctant to impose liability for refusals to supply was its concerns that liability forces courts to be price regulators. ${ }^{201}$ Conversely, Australasian courts are unconcerned. The only case to mention it was BOPE, where the Court recognised the concern's logic. ${ }^{202}$ However, this was obiter and the concern has troubled no other court. The Queensland Wire High Court merely sent questions of relief back to the Federal Court, while in NT Power the High Court accepted s 46 can create access regimes. ${ }^{203}$ It acknowledged that it can be difficult to frame injunctions granting access, but considered that this was no reason to deny s 46 applying. If the difficulties were insuperable the Court could grant other relief. ${ }^{204}$

Further, Verizon's concern that forced sharing may facilitate collusion does not worry Australasian courts as, again, BOPE is the only court that has even mentioned it. ${ }^{205}$

The way that the High Court of Australia framed the counterfactual in NT Power involving a natural monopoly or network industry will lead to increased liability. Any such counterfactual will involve a competing network with capacity, and refusing to supply will result in losing business to that competing network. In such circumstances it would never be rational to refuse to supply. This reasoning means that network industries that refuse to supply will have taken advantage of their market power.

Further, the High Court in NT Power rejected a property rights argument that was influential in Verizon. ${ }^{206}$ Protecting innovation and investment incentives did not impress the High Court. The reason may well be that, as Ahdar notes, many New Zealand firms with substantial market power did not grow from scratch. ${ }^{207}$ They were former state-owned enterprises. They had market power thrust upon them. The incumbent neither innovated nor invested in creating its facility or network. Given

200 At 193, 197, 202, 208 and 216.

201 Verizon, above $\mathrm{n} 13$, at 408 .

202 BOPE, above n 10, at [374].

203 NT Power, above n 114, at [85] and [122]-[126].

204 At [79].

$205 B O P E$, above n 10, at [379].

206 NT Power, above n 114, at [85] and [122]-[126].

207 Ahdar, above n 3. 
this, property rights arguments based on protecting an incumbent's incentives to innovate do not apply.

Another reason why New Zealand law is tougher on unilateral refusals to supply than United States law is that the Court of Appeal in Data Tails has reduced the importance of efficiency in New Zealand. Prior to Data Tails New Zealand courts had stressed how important efficiency was under s 36 and refusals to deal. One sees this in how often Australasian courts had cited Judge Posner in Olympia Equipment Leasing Co $v$ Western Union Telegraph Co where he observed:208

... the lawful monopolist should be free to compete like everyone else; otherwise the antitrust laws would be holding an umbrella over inefficient competitors. "A monopolist, no less than any other competitor, is permitted and indeed encouraged to compete aggressively on the merits ..."

Today it is clear that a firm with lawful monopoly power has no general duty to help its competitors, whether by holding a price umbrella over their heads or by otherwise pulling its competitive punches.

These comments have been influential. The Full Federal Court in Queensland Wire cited them and also noted how under United States law "the emphasis of antitrust policy shifted from the protection of competition as a process of rivalry to the protection of competition as a means of promoting economic efficiency". 209

In Queensland Wire the High Court also noted Olympia, ${ }^{210}$ while in Clear v Telecom the High Court cited the same extract as the Full Federal Court, saying the decision was "a classic exposition of the obligations and rights of a firm possessing monopoly power". ${ }^{211}$ The High Court cited a passage where Judge Posner referred to the essential facilities and monopolistic refusal to deal cases as qualifying the comments on monopolists having no duty to help competitors: ${ }^{212}$

... the monopolistic-refusal-to-deal cases qualify rather than refute the no-duty-to-help-competitors cases. If a competitor is also a customer his relationship to the monopolist is not a competitive one. The monopoly supplier who retaliates against customers who have the temerity to compete with him, by cutting such customers off, is severing a collateral relationship in order to discourage competition.

The essential feature of the refusal-to-deal cases - a monopoly supplier's discriminating against a customer because the customer has decided to compete with it ...

208 Olympia Equipment Leasing Co v Western Union Telegraph Co 797 F 2d 370 (7th Cir 1986) at 375.

209 Queensland Wire, above n 144, at [35].

210 Queensland Wire, above n 7, at 191.

211 Clear Communications, above n 134, at 194.

212 At 196 citing Olympia, above n 208, at 376-377. 
The Privy Council also favourably cited the "holding an umbrella over inefficient competitors" comments in Telecom v Clear. ${ }^{213}$ BOPE noted this. ${ }^{214}$

Only the High Court in Clear v Telecom noted Judge Posner's qualification on the primacy of efficiency. This is ironical as Olympia did not involve an entrant seeking access to a defendant's facility to compete. The defendant in that case, Western Union, provided telex services which required users to have telex terminals. Western Union required customers to lease their terminals from it. It then decided to quit providing terminals. The plaintiff, Olympia, formed to take advantage of Western Union leaving the equipment market to get customers for Olympia's terminals. It relied on referrals from Western Union as it had no sales force. Western Union gave customers a list of vendors of terminals including Olympia. As the liquidation of its equipment was going too slowly Western Union stopped supplying the vendors list. Olympia, without its own sales force went out of business and sued claiming that refusing to supply the list breached $\mathrm{s} 2$.

This is not the classic refusal case. Western Union and Olympia were not competitors. Western Union did not sell terminals whereas Olympia did. Olympia did not buy terminals from Western Union. Olympia alleged s 2 required Western Union to continue the sales support for telex vendors. The "helping hand" comments are in that context and they did not apply to essential facilities and refusals to supply.

Judge Posner's Olympia comments are consistent with his extrajudicial writings where he has advocated an equally efficient competitor test for monopolisation. ${ }^{215}$ This requires that "the challenged practice is likely in the circumstances to exclude from defendant's market an equally or more efficient competitor". ${ }^{216}$ If a plaintiff shows this "the defendant can rebut by proving that although it is a monopolist and the challenged practice exclusionary, the practice is, on balance, efficient". ${ }^{217}$ The rationale is "that a firm should not be penalised for having lower costs than its rivals and pricing accordingly". 218

By citing Olympia New Zealand courts arguably adopted an equally efficient competitor test. Telecom v Clear, where the Privy Council blessed the ECPR, is consistent as it requires an access

213 Telecom, above n 132, at 402.

$214 B O P E$, above n 10, at [385].

215 Posner, above n 89, at 194-195.

216 At 195 .

217 At 195 .

218 Herbert Hovenkamp "Exclusion and the Sherman Act" (2005) 72 U Chi L Rev 147 at 154. 
seeker to be at least equally efficient to the incumbent. So too is predatory pricing law which requires a defendant's prices to be below cost. ${ }^{219}$ Data Tails has changed this.

The Court of Appeal read the Privy Council in Telecom as requiring that an incumbent charge an access price that enables an entrant to compete. Charging a price that would prevent a firm from entering would breach s $36 .{ }^{220}$ The Privy Council noted Clear had not established: ${ }^{221}$

... that Telecom's charges will be so high that Clear will be unable to enter the [central business district]

market at all. ... Clear could not make any factual case that it would be altogether prevented by the level

of Telecom's charges from entering the market at all.

This is contrary to Olympia. The ECPR requires an entrant to be as efficient as the incumbent. If Clear could not compete under ECPR prices that meant it was not as efficient as Telecom. Under Olympia, if Clear could not pay ECPR prices and compete then a court should not grant access as it would be holding an umbrella over inefficient rivals. Yet it is evident that if Clear had shown that ECPR prices meant it could not compete then Telecom would have breached s 36.

By focusing on whether a price is too high to allow an entrant to compete the Court in Data Tails ignored efficiency. The entrant's efficiency as compared to the incumbent's is irrelevant. The Court also endorsed Ahdar's comments on Telecom where he said that s 36 embraces conduct that seriously restricts or deters competition. ${ }^{222}$ This too emphasises the entrant and views things from its perspective. That the entrant may have been inefficient is irrelevant. This downplays Olympia and suggests that, in relation to access seekers to a network, incumbents must give the entrant a helping hand.

As an aside, the Court's comments conflict with how it defined price squeezes. It said: ${ }^{223}$

A price squeeze occurs when a dominant vertically integrated supplier sets prices in the upstream wholesale market in a manner that prevents equally or more efficient competitors from profitably operating in the downstream retail market.

This requires the access seeker to be at least an equally efficient competitor and is consistent with the ECPR and Olympia.

219 Carter Holt Harvey Building Products Group Ltd v Commerce Commission [2004] UKPC 37, [2006] 1 NZLR 145 .

220 Data Tails, above n 4, at [236].

221 Telecom, above n 132, at 407.

222 Data Tails, above n 4, at [236] citing Rex Ahdar "Battles in New Zealand's Deregulated Telecommunications Industry" (1995) 23 ABLR 77 at 104.

223 At [2]. 
The Court's views are consistent with Queensland Wire where BHP's pricing breached s 46. The High Court variously described BHP's price as "excessively high" and not at a "reasonable price" or not at "a competitive price" and "an unrealistically high price". ${ }^{224}$ It did not define these terms. The trial judge observed "the offer made by BHP was pitched at a level which BHP knew would make it impossible of acceptance, because [QWI] could not manufacture star picket from Y-Bar purchased at that price and sell it competitively". ${ }^{225}$ This meant that BHP would not have breached s 46 had it supplied Y-Bar at a price that enabled QWI to compete with BHP in selling star picket fences. This is consistent with the Privy Council in Telecom as BHP's price was so high that QWI could not enter the market.

Queensland Wire does not mention efficiency in the sense of requiring the entrant to be equally as efficient or ensuring total efficiency. It is contrary to the equally efficient competitor standard as it focuses only on the survival of the access seeker. This is important as it gives substance to the third assumption in NT Power of providing access on reasonable terms and conditions. ${ }^{226}$ A reasonable price would not breach s 36. From Data Tails and Queensland Wire this must be a price that enables an entrant to compete. The Privy Council in Telecom opposed asking whether the defendant acted reasonably or with justification. ${ }^{227}$ The Court in NT Power was not opposed, and if "reasonable terms and conditions" includes an access price that enables an entrant to compete profitably then neither should the Privy Council have been.

This tough stance towards unilateral refusals to supply shows that New Zealand has its own de facto essential facilities doctrine. BOPE was correct on this. With network industries the NT Power reasoning will mean refusing to supply will invariably lead to liability. Only if the High Court's three assumptions are not possible would liability not arise. If the defendant lacked capacity to supply or had a legitimate business reason for not supplying, then a court would not order supply. A legitimate business reason for not supplying means that a court could not assume that the defendant would grant access on reasonable terms and conditions. This is the $M C I$ formulation of the essential facilities doctrine. NT Power goes further as the High Court rejected a property rights argument.

\section{BOPE'S FAULTY REASONING}

$B O P E$ in endorsing Queensland Wire entails more liability than the United States law under Verizon allows and is an essential facilities doctrine in all but name. However, in deciding New Zealand has an essential facilities doctrine the BOPE Court took the wrong path in reaching this destination. It misinterpreted case law and ignored relevant authorities.

224 Queensland Wire, above n 7, at 185, 193, 197 and 216.

225 Queensland Wire, above n 144, at 61.

226 NT Power, above n 114, at [177]-[178].

227 Telecom, above n 132, at 403. 
The Court's views on legitimate business rationale and s 36 proved to be inaccurate. BOPE submitted that legitimate business rationale was important in establishing "take advantage"; in other words, if a firm has a legitimate business rationale for a refusal to deal it has not taken advantage of its market power. ${ }^{228}$ While it cited the Boral Federal Court ${ }^{229}$ it failed to say the Boral High Court and the Privy Council in Carter Holt Harvey both approved the Federal Court's reasoning on legitimate business rationale. ${ }^{230}$ BOPE claimed the Melway High Court also endorsed Boral's comments on legitimate business rationale. ${ }^{231}$ Melway did not mention it. BOPE rejected the submission saying this approach begged the question as such a test would not capture conduct which might be legitimate for a firm that lacked market power but would be anticompetitive when a monopoly carried out that same conduct. ${ }^{232}$ This is problematic. The Melway High Court discussed this, ${ }^{233}$ citing Scalia J's comments in Eastman Kodak where he observed:234

Where a defendant maintains substantial market power, his activities are examined through a special lens:

Behavior that might otherwise not be of concern to the antitrust laws - or that might even be viewed as

procompetitive - can take on exclusionary connotations when practiced by a monopolist.

BOPE mentions neither case and seems unaware that Eastman Kodak endorsed the legitimate business rationale as a defence for monopolisation. ${ }^{235} B O P E$ also claimed that Verizon held that a defendant does not breach s 2 if its conduct has a legitimate business rationale. ${ }^{236}$ Verizon does not discuss legitimate business rationale. Furthermore, BOPE, in downplaying legitimate business rationale, was not prescient as the New Zealand Supreme Court subsequently adopted Heerey J's comments in Boral saying he had "captured the essence of the comparative exercise necessary to determine whether use had been made of market power". 237

228 BOPE, above n 10, at [312]-[313].

229 Australian Competition and Consumer Commissioner v Boral Ltd [1999] FCA 1318, (1999) 166 ALR 410.

230 Boral Besser Masonry Ltd v Australian Competition and Consumer Commissioner (ACCC) [2003] HCA 5, (2003) 215 CLR 374 at [170]; and Carter Holt Harvey, above n 219, at [54].

231 BOPE, above n 10, at [312].

232 At [317].

233 Melway, above n 106, at [29].

234 Eastman Kodak, above n 33, at 488.

235 At 483 .

236 BOPE, above n 10, at [376].

237 Commerce Commission v Telecom Corporation of New Zealand Ltd [2010] NZSC 111, [2011] 1 NZLR 577 at [26]. 
BOPE referred to four purported essential facility authorities. ${ }^{238}$ These were: ARA, Port Nelson, ${ }^{239}$ Queensland Wire and Telecom v Clear. The Court's treatment of these was troublesome. As for Port Nelson, BOPE referred to Port Nelson Ltd v Commerce Commission in the Court of Appeal. This case was not a refusal to deal and the Court did not mention essential facilities. However, Union Shipping $v$ Port Nelson Ltd involved a refusal to deal and though the High Court discussed essential facilities it declined to incorporate the doctrine into New Zealand law. ${ }^{240}$ So BOPE referred to the wrong Port Nelson case.

One could treat Telecom v Clear as involving essential facilities; but doing so does not advance things. Only the Court of Appeal mentioned the doctrine and then only for the insights it provided. As Telecom had undertaken to grant Clear access no court discussed whether s 36 obliged Telecom to supply.

$A R A$ discussed essential facilities but is not persuasive as the doctrine was not the basis for the decision and the case did not involve an incumbent refusing to supply a rival.

BOPE said Queensland Wire is the best example of an essential facilities case that obliges an incumbent to supply an access seeker. It further said the Queensland Wire approach - rather than the United States version - applies when courts will oblige a firm to supply. ${ }^{241}$ BOPE claimed Queensland Wire established the following criteria: first, an essential facility or input is one that must not be practically duplicable, must have no close substitutes and must be necessary for competition in the market; and second, the defendant must control the facility or input. ${ }^{242}$

The criteria are consistent with United States law, but it is ironical that BOPE regarded Queensland Wire as establishing an essential facilities doctrine as the Full Federal Court not only rejected the doctrine applying to s 46 generally but also to the defendant, BHP. The Court did not see the doctrine as applying outside monopolies of electric power, transport, communications, or some other "essential service". Y-Bar as a product was not an essential service. ${ }^{243}$ The High Court was silent on the essential facilities doctrine.

BOPE mischaracterised Queensland Wire. It claimed the High Court commented there were no other steel manufacturers to supply Y-Bar. The High Court did not. Rather, it said that Smorgons was a substantial domestic competitor of the defendant in supplying steel and steel products and the

238 BOPE, above n 10, at [373].

239 Port Nelson Ltd v Commerce Commission [1996] 3 NZLR 554 (CA).

240 Union Shipping, above n 149.

$241 B O P E$, above n 10, at [387].

242 At [388].

243 Queensland Wire, above n 144, at [38]. 
defendant was concerned that Smorgons was interested in producing Y-Bar. ${ }^{244}$ While it found that the defendant had substantial market power in steel and that there were barriers to entry, that is not saying that there were no other steel manufacturers to supply Y-Bar. Mason CJ and Wilson J said it was relatively easy for an existing steel producer to convert production from one shape of steel to another. ${ }^{245}$ This included Smorgons. Other sources of Y-Bar were available. ${ }^{246}$ This shows Y-Bar did not fall within BOPE's definition of an essential facility.

Surprisingly, BOPE does not discuss NT Power, which is the most relevant essential facilitiestype case and introduced the doctrine into Australasia. Perhaps the reason is the case does not use the terminology of "essential facilities", but as Berry has pointed out the case involved a classic essential facility and shows how s 36 applies and captures such situations. ${ }^{247}$

\section{CONCLUSION}

New Zealand's law on unilateral refusals to supply is far stricter and results in more liability than United States jurisprudence. While United States law has moved away from the essential facilities doctrine, New Zealand, albeit partly due to faulty reasoning in BOPE, has embraced it. This stricter stance is justified as maintaining innovation incentives is less important in New Zealand than the United States and the small size of many New Zealand markets means customers will often depend on a sole supplier. Without alternative sources of supply a refusal to supply will cause competitive harm. Given this state of affairs it is ironical that there are calls to amend s 36.

244 Queensland Wire, above n 7, at 183-184 and 201.

245 At 192.

246 Warren Pengilley "Hilmer and Essential Facilities" (1994) 17 UNSWLJ 1 at 19, n 58.

247 Mark Berry "Competition Law" [2006] NZ L Rev 599 at 605-607. 